\title{
InRA: An Imagery Technique to Improve Reading Skills of Arabic Single Vocal "A" Alphabets
}

\author{
Rozaini Tukimin, Nik Mohd Rahimi Nik Yusoff, Harun Baharudin \\ Faculty of Education, National University of Malaysia, Bandar Baru Bangi, Malaysia \\ Email: P90454@siswa.ukm.edu.my
}

How to cite this paper: Tukimin, R., Yusoff, N. M. R. N., \& Baharudin, H. (2019). InRA: An Imagery Technique to Improve Reading Skills of Arabic Single Vocal "A" Alphabets. Creative Education, 10, 1850-1862. https://doi.org/10.4236/ce.2019.108133

Received: July 19, 2019

Accepted: August 11, 2019

Published: August 14, 2019

Copyright $\odot 2019$ by author(s) and Scientific Research Publishing Inc. This work is licensed under the Creative Commons Attribution-NonCommercial International License (CC BY-NC 4.0). http://creativecommons.org/licenses/by-nc/4.0/ (c) (i) (8) Open Access

\begin{abstract}
Imagine and Read Arabic-InRA is a form of intervention strategies through the design of teaching material as an alternative to overcome the problem in recognizing and reading Arabic letters among students in the basic education level. Innovation is highlighted from the point of teaching techniques and aids learning reading skills of 29 Hija'iyyah Arabic Alphabets of single vowel "A" in teaching and learning Arabic language in primary schools. The usage of this innovation will not only overcome the issue of identifying and reading but also even train students of basic Arabic writing techniques. It is compatible with the objectives of the Curriculum Standard of the Arabic Language for Year 1 KSSR Revision and the initial curriculum for Year 2 to 6 to ensure that students can read and write Arabic Hija'iyyah Alphabets correctly. This innovation is devoted to the use of rehabilitation activities in the classroom of teaching Arabic language subject through the application of multiple intelligences. A total of 20 students from Year 1 were exposed to teaching aids using the charts that are designed graphically using picture icons which resemble certain Hija'iyyah Alphabets for 7 weeks with a focus on 4 - 5 letters per week. Post-test results found that $100 \%$ sample students have successfully mastered those skills. The implementation of technology applications AR (Augmented Reality) and QR Code also adds an element of edutainment in aids designed for the purpose of self-access learning that characterizes the 21 st century teaching and learning.
\end{abstract}

\section{Keywords}

Innovative Teaching, Innovative Teacher, Imagery Techniques, Arabic Language Education, Innovation

\section{Introduction}

The skill of reading Arabic alphabets of Fathah lines is fundamental in learning 
Arabic texts. However, there were Muslims, including students in the school who have not yet mastered reading of the Hija'iyyah alphabets and the pronunciation of less precise articulation point of the letters (Yusoff \& Suratem, 2015; Mat et al., 2016). Yanti Munirah Jusoh (2013) identified several causes for this problem. Among them is a pupil that cannot master the spellings and have difficulties in identifying letters, lack of teachers' skills in teaching methods to teach spelling lines and punctuation of the letters, reading books that are less attractive in terms of graphical presentation and color, the pattern of teaching that is more on the interaction of one-way and the usage of memorizing approach that dominates the teaching process. The weakness of approaches and practices of teachings makes the teaching of reading letters that forms the basis of Hijaiyyah reading of the text in Arabic and Quran to be less attractive and difficult to master (Che \& Tirmizi, 2009). This scenario is feared to lead to the weakness in the reading of the verses of the Quran that becomes the basis of worship (Che \& Tirmizi, 2009).

The usage of imagery techniques in second language learning is seen as a variety of skills that have the potential to be an alternative method to overcome these reading Hijaiyyah alphabets. The use of this approach has been widely discussed from various angles over the past decade on the issue of whether language acquisition aspects of teaching grammar, vocabulary learning, reading, writing, listening and comprehension aspects. Past studies have used a variety of methods based on imagery technique that uses imagination to improve their second language learners (Chan, 2013; Gerngross et al., 2006; Green \& Donahue, 2009; Chen, 2015; Wright \& Hill, 2008; Freeman \& Robertson, 1999).

The development of instructional teaching set called InRA, which is an acronym for the word Imagine and Read Arabic, is a formulation and combination of the application of various theories of thought, learning, various intelligence and teaching strategies. Therefore, what is stressed in its construction is the aspect of teaching strategies using this material. This is an iconic approach brainchild of its creation and existence of a writing system itself in the history of early human civilization which began to form in ancient Egyptian society known as hieroglyphs.

This study will focus on a number of stages in the construction process of the material based on action research.

\section{Literature Research}

The construction of teaching aids of recognition and reading of the Hija'iyyah Arabic language alphabets is deeply concerned with the theory of cognitive, behavioral and neurobiological. Students with low achievement and poor memory capacity need to be exposed to a lot of concrete experience and the actual situation of this experience to enable it to build a clear mental picture and understand the concepts of the lessons properly. According to Cognitive Learning Theory by Jean Piaget, children at the lower level is able to solve problems involving con- 
crete objects (things that can be seen or touched) and many use the existing experience to understand the new experience (Piaget, 1964).

Students with low achievement and in need of rehabilitation teaching in primary school in which their cognitive capacity is still childlike, is subjected to ability that is limited, and developed throughout their age. Also stated by Shamsudin (2012), rehabilitation students if paid close attention to on the aspect of their IQ intelligence test, their cognitive development is found to be slower than their age which is their mental age is much lower than their birth date. Thus, it can be concluded that the level of their thinking is between Pre-Operation zones, zones 2 - 7 years and Concrete Operation zones, 7 - 11 years.

In fact, cited by Dr Ragbir Kaur Joginder Singh (2012) that at this age, behavior, knowledge and learning process of many students occur as a result of imitation as proposed by Albert Bandura Modelling Theory. Among the types of children's learning in the first step is to copy and play. In the discussion of the theory of language, this opinion is held by Nativist Theory which they believe that children acquire language naturally in social processes without having to be trained or coerced because naturally people do have the ability to master the language and there is a kind of device found in their bodies called Language Acquisition Device (Chomsky, 1969; Vygotsky, 1975). Their language acquisition begins with the mother tongue and later expanded to the new language through experience. Similarly, Vygotsky's theory supports which holds that children learn language by imitating or repeating what is heard or experienced in his lifetime. Children receive support from adults to master the basic skills of speaking.

According to the approach of Neurobiology, optimal learning can be generated through the integration of the left and right brain activity of which it can develop brain cells with some stimulation activities. According to Abdul Fatah Hasan (1994), one of the stimulus to the development of brain cells, is when our eyes see things. Using stimulus through picture or image is closely related to the perception and this stimulus can be easily detected by the sensory organs. According to Koffka (2013) through the Principles of Gestalt Psychology and quoted by Mok Soon Sang (2003), the perception on the forms or things that being seen and observed depends on the existing experiences. For example, children who experience past often see the character of Batman will observe some teeth in the human mouth as Batman logo. This process is also called assimilation by Jean Piaget (1964), which occurs when the child incorporates new elements into the structure of the behavior, environment, existing knowledge or experience. In Azizi Yahaya et al. (2008), cognitive development of children occurs through observation of the natural environment. According to Mok Soon Sang (2008), the importance of existing knowledge in the acquisition of new knowledge was submitted by the Learning Theory of Reception by David P. Ausubel.

According to Cognitive Theory by Jerome Bruner cited by Mohd Ismail (2013), child development is going through three stages which are the enactive, 
iconic and symbolic stages. At the enactive or concrete stage, children learn through observation and direct experience with the use of sensory motor learning where materials and objects realized. As referred to Nurul Amirah Mohd Razali \& Zaidatun Tasir (2008), at this stage, children should be given a strong experience, therefore what they have learnt by doing activities will be stored in long-term storage. On the iconic stage, children learn through pictures and verbal visualization in understanding the surrounding world. When they have reached a symbolic stage, the mastery of abstract ideas was influenced by the language, logical thinking and as well as a communication by using symbol system. Normally, students with poor reading skills are at the stage of enactive and iconic.

Innovative teaching strategies like imagery strategy are necessary to improve memory and mastery in reading because this strategy provides concrete experience to the students. Construction mental images (Mental Imagery) known by various terms in the academic world, especially in psychology and cognitive such as mental imagery, visualization and seeing through the mental eyes is an alternative that is believed by many scholars can play a very important role in the formation of memory (Clark \& Paivio, 2004).

Mental Imagery is defined as the activity reflects a certain result before the result is achieved through a process of imagination (Korn \& Johnson, 1983) or a process or event when the individual feels a significant effect on an object, event or specific scenes, but the objects, events and the atmosphere is actually none-existent at the moment of mental representations occur in the brain. It was born from the process of recall visual objects, events seen in the past and those experienced previously (Richardson, 2013). Based on this theory, which involves visual sensory channels, eyes that see and verbal channels involving a listening ear sensory are processed separately. However, when the information processing takes place simultaneously will result in memory and mental images built better and stronger during the process of recall (Paivio, 1990; Mayer, 2002).

Imagery approach used in the fields of education, particularly in learning a second language and foreign language is called mnemonic techniques (Paivio, 1980). There are several techniques used under the mnemonic approach, which is a technique of loci, rhyme technique and keywords technique. Keywords technique has been applied in the design of innovative aids of Hijaiyyah alphabets single vowel "A" because this technique builds relationships between sounds and images by associating something unusual and foreign word with the words of native language learners. The series of images are built into a clue for the meaning of certain foreign words that seems easier to memorize. The difference is that the technical aspect of this innovation is not relevant to the pronunciation of the word but to the sounds of the Arabic letters. This technique is found to be very effective for children at the primary level, even more with the help of pictures as stimulus for their memory because they are still not able to generate the images of their own to build the relationship between the keyword and the word (Atkin- 
son, 1975; Paivio, 1980).

\section{InRA Development: An Action Research}

In the early stages of this InRA aids development, action research is conducted on primary school pupils. According to Lomax (1994), an action research is aimed at solving the problems faced by teachers. Action research is conducted in accordance with the Kemmis and McTaggart Model (1998). According to this model, action research involves in four stages or steps, i.e.; Stage I: Reflecting, Stage II: Planning, Stage III: Action and Stage IV: Observation.

\subsection{Reflecting Stage}

The position before these innovation materials are used in the teaching of reading skills of the Arabic language, it was found that there were still pupils in Year 1 who were problematic in reading of the Arabic single vocals of Fathah lines while the Arabic language curriculum syllabus taught at that moment has entered a multi-line reading skills. Thus, at the reflecting stage, data on student proficiency levels in reading Arabic single vocals of Fathah lines obtained through a number of instruments of observation, pre-test form, and informal interviews with Tasmik teachers.

\subsubsection{Observation}

The results of the observations of researchers who are given the responsibility of teaching Year 1 Amanah for the subject of Arabic language, it was found that there are some students who are less proficient at reading some of the Arabic single vocals of Fathah lines letters even being studied in pre-school and during the Islamic Studies period. Most of them found it difficult to recognize and read the pronunciation of the letters which almost have the same form as ( $\overline{\boldsymbol{\tau}}$ and $\dot{\boldsymbol{\tau}}$ ),

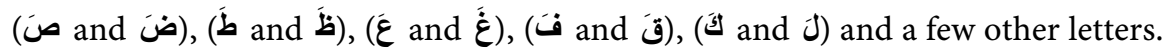
Furthermore, the teaching of Iqra' reading skills in the syllabus of Islamic education is taught at a fast pace and causing pupils who lack skills to be continued to be left behind. As a result, the weakness of pupils in reading Iqra' will also have an impact and contribute to their inability to read the Arabic clause.

\subsubsection{Pre-Test}

The purpose of the test is to detect the level of pre-reading skills of students through pre-test form that lists 29 single Arabic alphabets of Fathah lines. In this form, the pre-test is designed with a list of Hijaiyyah letters arranged alphabetically in sequential order and there are little boxes provided below each letter for the usage of teachers marking whether students can read it or not. While at the bottom of the form there is a record to be filled by the teacher whether students master reading or not.

The reading test was taken place face-to-face between students and teacher. This test was to look at the ability of the students of Year 1 Amanah which are seven years in age to read the letters and to identify the letters that cannot be 
remembered based on their previous knowledge. This test also served as a screening tool to identify the samples needed for intervention implementation. As a result of the pre-test, it was found that 11 of the 31 pupils in Year 1 Amanah mastered reading of all the alphabets listed. While another 20 students consisting of 9 males and 11 females have not been able to read some of the alphabets. The analysis results are as follows (Table 1 ).

It was found that as many as $30 \%$ of the sample students master reading of less than half the number of Hijaiyyah alphabets of Fathah lines and the remaining $70 \%$ accounted for more than half the number of letters of 16 point upward.

Deeper analysis has been made related to the alphabets of the easiest and the most difficult to master by 20 students sampled. This is shown by the following graph.

Based on the Graph 1 below, it was found that most students did not master the last half of the registered alphabets. Alphabets were found most difficult to read by the majority of students is $(\dot{\xi})$. While the alphabets which are most easily to be remembered in reading is (I) since it was in the very beginning.

\subsubsection{Interview}

Some informal interviews were also conducted with Iqra' Tasmik teachers who taught Year 1 Amanah:

"... Some are okay... some have troubles in memorizing..."

“... Yeah today we teach ... they'll forget again tomorrow ... and then reciting for a bit and then they'll play a lot...” (GPI01).

"... Whenever Tasmik is in session they will always want to go to the toilet..."

“... I don't know. For the easier letters is okay but they are still confused with the letters that are almost the same..."

Table 1. Pre-test result findings and number of alphabets mastered by pupils $(\mathrm{N}=20)$.

\begin{tabular}{ccc}
\hline No. of Sample & Gender & Number of Alphabets Mastered \\
\hline S1 & Male & 21 \\
S2 & Male & 5 \\
S3 & Female & 24 \\
S4 & Male & 8 \\
S5 & Male & 22 \\
S6 & Male & 15 \\
S7 & Male & 1 \\
S8 & Male & 9 \\
S9 & Female & 12 \\
S10 & Female & 8 \\
S11 & Female & 22 \\
S12 & Male & 16 \\
S13 & Female & 11 \\
S14 & Female & 16 \\
S15 & Female & 14 \\
S16 & Female & 14 \\
S17 & Female & 11 \\
S18 & Female & 14 \\
S19 & Male & 14 \\
S20 & Female & 13 \\
\hline
\end{tabular}




\section{Graphic of Reading Mastery of Arabic Vowel "A" \\ In Pre-Exam}

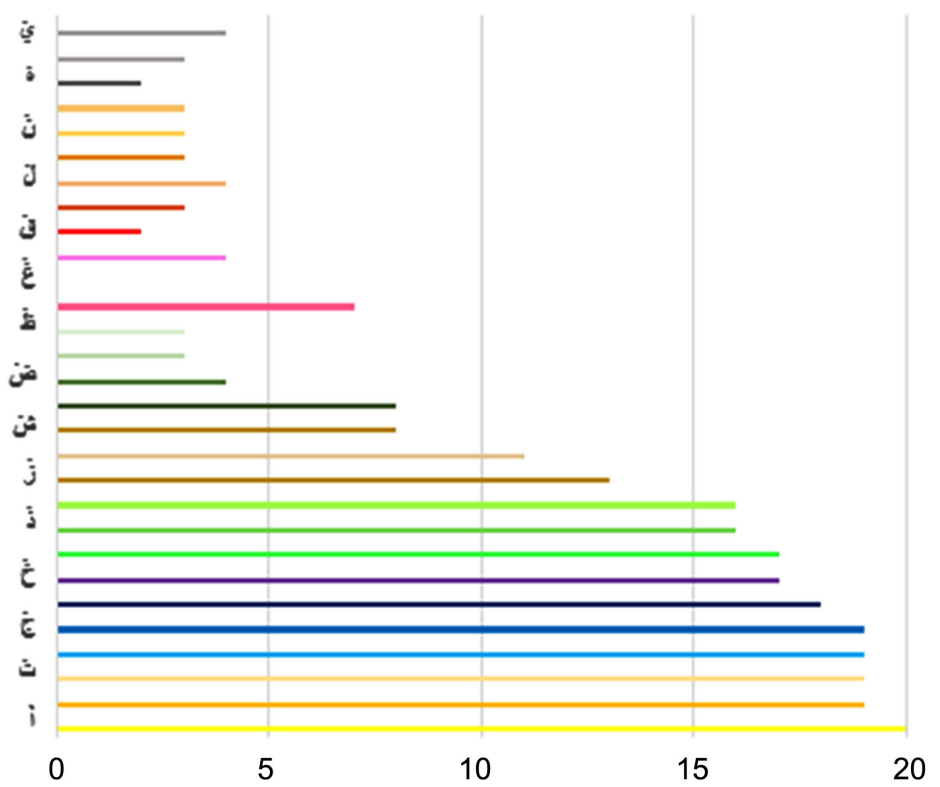

Graph 1. Level of students mastery according to the alphabets.

"... Have to repeatedly teach them until they can understand and memorize...” (GBA01).

“... Its hard... Tasmik session is very short so a lot of them doesn't understand and memorize any of the letters... they read it very briefly and some had no opportunities in doing the Tasmik. Cannot focus on one student for too long..." (GPI02).

Therefore, based on observation findings, pre-test and interviews have identified some major problems in the teaching of reading the Hijaiyyah Alphabets of Fathah lines:

- The problem of alphabet recognition and the difference between several alphabets of about equal shape/form.

- The problem of students' focus who prefer to play.

- The problem of students' memory capacity.

- Limited teaching and learning period, many students with different skills and multiple intelligence.

- Less interesting activities.

Hence, the researcher sees the need for a solution in the form of auxiliary materials that can overcome the problems. The construction of the innovation material is also trying to take into account the solutions to these problems as much as possible.

\subsection{Planning Stage}

The development of this innovative material in the teaching skills of recognition and reading of the Arabic alphabets is one of the efforts in teaching and learning 
strategies based on resources and materials as well as student-centered teaching and learning strategies to facilitate students to understand the teachers' teaching and quickly remember the lessons (Tukimin et al., 2018).

The teaching pronunciation of the 29 Hijaiyyah Arabic alphabets based on the diagram are used as an alternative for available reading materials such as Iqra' books and Iqra' charts which only display forms of writing of Hijaiyyah alphabets solely and seems abstract for students with weak cognitive skills and looks "holy" to be learned by non-Muslim students. The creation of this material is expected to attract non-Muslim students to learn the Arabic language in order to master the reading skills which are also found as a highly significant aspect of weaknesses in teaching Arabic language to this group. Whereas the teaching of Arabic is not the teaching of religion.

The results of a literature review on all the theories, the researchers worked on a number of features to ensure that this teaching aids are built really well and can overcome reading problems of the 29 Hijaiyyah Arabic alphabets of Fathah lines among pupils who are low-achievers in teaching and learning Arabic Language, Tasmik activities (Iqra' reading guidance) and Quran Literacy Camp (Quranic recovery program). Among the characteristics are:

- Less interesting activities.

- The use of multi-purpose charts and multipurpose cards is one of the preferred learning aid materials.

- Use image icons as stimuli.

- Take into account the existing experience and knowledge of the students.

- Application of mimicry activity from the natural surroundings of pupils.

- Multiple intelligence applications in innovation.

- The use of reinforcement activities through the use of AR (Augmented Reality) technology through the HP Reveal/Aurasma apps medium featuring mobile object images and sound when the smartphone camera focuses on the writing and drawing on the charts as memory stimuli and elemental comforts.

- This pictorial teaching lesson is an alternative to existing reading materials.

The use of technology applied as an additional feature of reading teaching aids is intended to reinforce abstract concepts of teaching to a meaningful learning. Technology application such as augmented reality provides a superior learning environment. Its interactive function transforms reading into a multiscale immersive experience (Billinghurst \& Duenser, 2012). Even though technology is not yet intelligent and perfect enough to be effective in students learning in all circumstances (Lai \& Kritsonis, 2006), important lessons must be learned and planned about how best to use it in an educational setting (Billinghurst \& Duenser, 2012).

To ensure a positive and maximum impact on its use, some aspects of the pupils are taken into account:

- The personality characteristics of the students. 
- Students' learning styles are pragmatic, imaginative, reflective or practical.

- Various forms of student intelligence.

- Brain management theory (Information processing model).

- Thinking skills are either reactive or reflective.

- Values.

Some teaching strategies are designed to be used in learning and facilitating steps by using InRA:

- Imagination support and guidance strategy.

- Body movement strategy.

- The Phonics, Mnemonic and Impersonation Pronunciation Strategy.

- HOTS Strategy (Questioning Technique).

Figure 1 below shows the design of the Imagine and Read Arabic (InRA) interface produced.

\subsection{Action Stage}

After a set of ready-made innovations and improvements, it is used in reading the Hijaiyyah Alphabets of Fathah lines of teaching and learning reading session in Year 1 Amanah for 7 weeks involving 20 students of 9 males and 11 females. Here are the steps undertaken for teaching and learning:

- Matching an image icon with the same or nearly identical alphabets.

- Sorting random cards alphabets on the teacher's desk. Students choose a card based on the teacher's pronunciation.
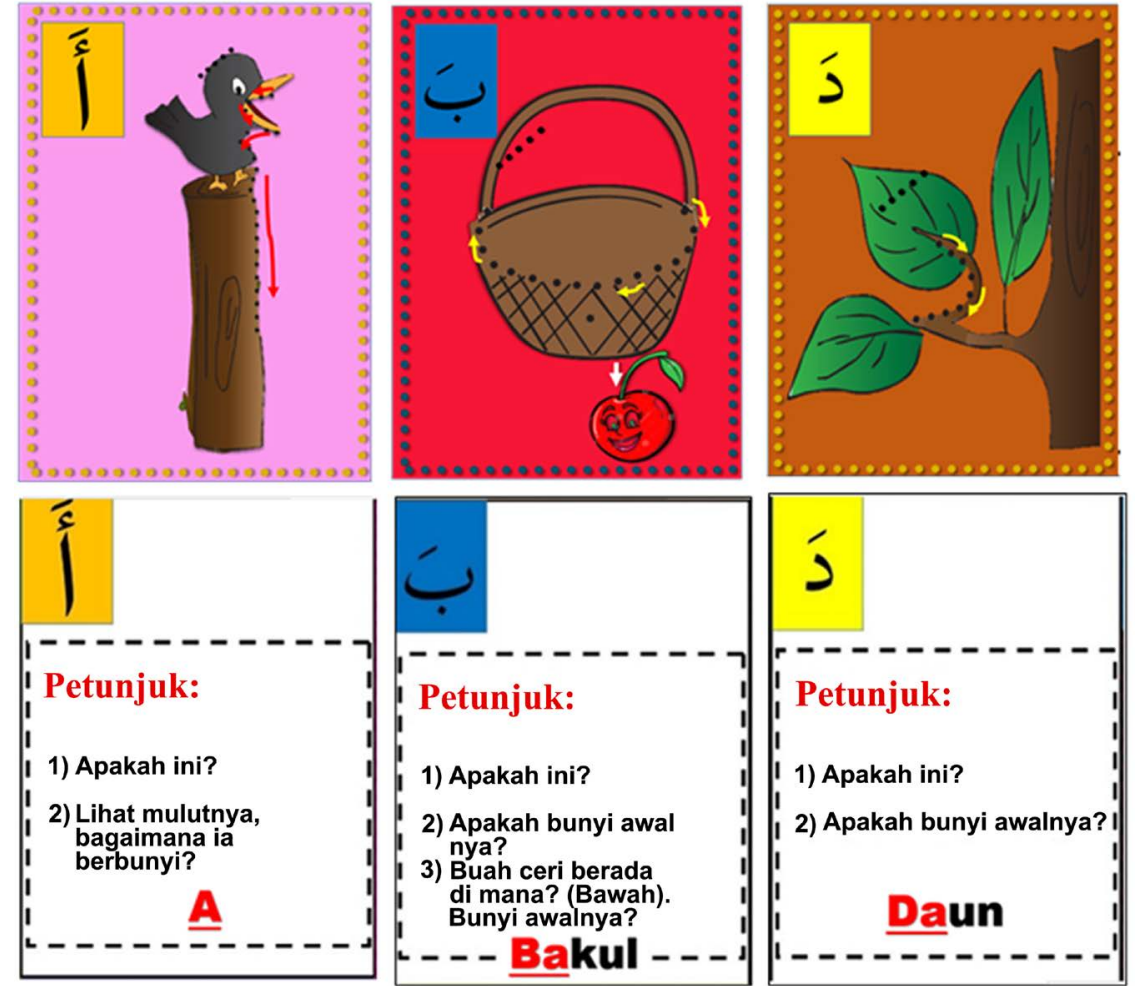

Figure 1. Imagine and read Arabic (InRA) interface. 
- Group activity by viewing and recognizing the shape of alphabet and alphabet icons then rewriting on striped sheets as reinforcement.

- Strengthening activities with quiz games using group cards.

- Strengthening activities by using Augmented Reality technology in which when a cell phone camera focused toward icons of the images or writing on the chart, it will come to live that is to extract video images, voices, singing or moving images and activities graft cuttings form alphabets using puzzle apps through the medium of the QR code.

- Evaluation and closing activities with recurring random alphabet cards.

\subsection{Observation Stage}

After going through the usage phase in Class 1 Amanah in teaching Arabic language, a post teaching-test was performed on a sample of 20 pupils to observe the effectiveness of the use of innovative aids Imagine and Read Arabic (InRA). The test was carried out by using a post-test of the same form with the pre-test. The difference is not just post-test carried out by order of the alphabets but randomly.

The effectiveness of the InRA innovation aids can be seen through the different pre-test score results and post-test to be carried out on all 20 test samples. Data retrieval of test results showed improvement in reading skills of the Hijaiyyah alphabets of Fathah lines after the intervention than before. Data are shown in detail in Graph 2 below.

The results of T-test between pre and post-test showed that there are differences between student achievement and intervention before treatment and after treatment intervention for reading the significant level of less than 0.05 as shown in Table 2 below.

\section{Conclusion}

The usage of imagery techniques in the field of education has long been debated

Table 2. T-test results for pre and post-test exam.

\begin{tabular}{ccccccc}
\hline \multirow{2}{*}{$\mathrm{n}=20$} & SD & SE Mean & $\mathrm{t}$ & $\mathrm{df}$ & Sig. (2 tailed) \\
\cline { 2 - 7 } & Mean & SD & 1.30888 & 11.842 & 19 & 0.000 \\
\hline $\begin{array}{l}\text { Pre-test score } \\
\text { Post-test score }\end{array}$ & 15.50000 & 5.85347 & & & & \\
\hline
\end{tabular}

Note. ${ }^{*}=$ Significant at $<0.05$.

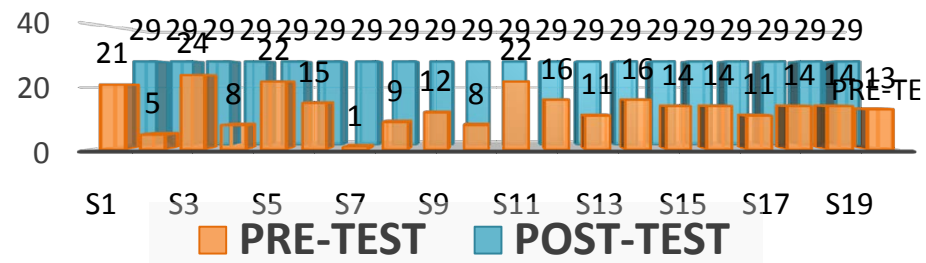

Graph 2. Difference of test score before and after intervention. 
by scholars earlier. Its effectiveness in helping to improve memory capacity and student achievement cannot be denied as included in language learning. However, its use in learning Arabic language is not so widely applied and needed to be proven through the data that are more robust statistically through empirical study. Although this technique is available in language learning strategy, there is little literature that specifically discusses the implementation of this technique in learning and teaching Arabic language especially that is related to learning the Arabic alphabets pronunciation. Innovative aids that applied this technique are still difficult to obtain.

The use of technology in the teaching and learning process has a great impact on students especially in primary school. The use of educational technology can make the teaching and learning process more active and create a fun learning environment. However, there are weaknesses in terms of their use that can be overcome by continuous improvement and innovation. Overall, it was concluded that the construction material for reading Arabic vocal alphabets of Fathah lines based on the imagery approach is potentially able to overcome the problem of recognition and learning to read Arabic language at primary school levels and has a high usability level. Hopefully, it can be an alternative to the existing aids to ensure improvement in students' achievement in the field of Arabic language.

\section{Conflicts of Interest}

The authors declare no conflicts of interest regarding the publication of this paper.

\section{References}

Atkinson, R. C. (1975). Mnemotechnics in Second-Language Learning. American Psychologist, 30, 821-828. https://doi.org/10.1037/h0077029

Billinghurst, M., \& Duenser, A. (2012). Augmented Reality in the Classroom. Computer, 45, 56-63. https://doi.org/10.1109/MC.2012.111

Chan, L. (2013). Motivation and Vision: An Analysis of Future L2 Self Images, Sensory Styles, and Imagery Capacity across Two Targets. Language Learning, 63, 437-462. https://doi.org/10.1111/lang.12005

Che, N. M. A., \& Tarmizi, R. A. (2009). Persepsi Pelajar Terhadap Amalan Pengajaran Tilawah Al-Quran (Students' Perception toward Teaching Tilawah Al-Quran). Jurnal Pendidikan Malaysia, 34, 93-109.

Chen, A. D. (2015). The Use of Verbal and Imagery Mnemonics in Second-Language Vocabulary Learning. Studies in Second Language Acquisition, 9, 43-61. https://doi.org/10.1017/S0272263100006501

Chomsky, C. (1969). The Acquisition of Language from Five to Ten. Cambridge, MA: MIT P.

Clark, J. M., \& Paivio, A. (2004). Extensions of the Paivio, Yuille, and Madigan (1968) Norms. Behavior Research Methods, Instruments, \& Computers, 36, 371-383. https://doi.org/10.3758/BF03195584

Fatah Hasan, A. (1994). Penggunaan Minda Yang Optimum Dalam Pembelajaran. Sku- 
dai: Penerbit UTM.

Freeman, L., \& Robertson, G. (1999). The Effect of Visual Imagery Training on the Reading and Listening Comprehension of Low Listening Comprehenders in Year 2. Journal of Research in Reading, 22, 241-256. https://doi.org/10.1111/1467-9817.00088

Gerngross, G., Puchta, H., \& Thornbury, S. (2006). Teaching Grammar Creatively. Cambridge: Cambridge University Press.

Green, M. C., \& Donahue, J. K. (2009). Simulated Worlds: Transportation into Narratives. In K. D. Markman, W. M. P. Klein, \& J. A. Suhr (Eds.), Handbook of Imagination and Mental Simulation (pp. 241-256). Hove: Psychology Press.

Ismail, M. (2013). Teori Belajar Jerome Bruner.

http://makalahpendidikanislam-lengkap.blogspot.com/2013/06/teori-belajar-menurut-j erome-bruner.html

Jusoh, Y. M. (2013). Pembangunan Aplikasi Cepat Membaca Al-Quran Untuk Platform Android (Mai Iqra). Skudai: Universiti Teknologi Malaysia.

Kemmis, S., \& McTaggart, R. (1998). The Nature of Action Research. The Action Research Planner. Victoria: Deakin University.

Koffka, K. (2013). Principles of Gestalt Psychology. Abingdon-on-Thames: Routledge. https://doi.org/10.4324/9781315009292

Korn, E. R., \& Johnson, K. (1983). Visualization: The Uses of Imagery in the Health Professions (pp. 209-213). Homewood, IL: Dow Jones-Irwin.

Lai, C. C., \& Kritsonis, W. A. (2006). The Advantages and Disadvantages of Computer Technology in Second Language Acquisition. Online Submission, 3.

Lomax, P. A. M. E. L. A. (1994). Action Research for Managing Change. In Improving Educational Management through Research and Consultancy (pp. 102-116). Thousand Oaks, CA: SAGE Publications.

Mat, M. Z. A., Sawarib, S. S. M., Puteh, A., \& Zubir, N. F. S. (2016). Identifikasi Kesan Kaedah Pintas Iqra Terhadap Tahap Penguasaan Huruf Hijayiyyah Dalam Kalangan Murid Sekolah Kebang-saan Di Malaysia. International Journal of Humanities Technology and Civilization, 1, 36-41.

http://www.myjurnal.my/filebank/published_article/59262/IJHTC_2v1n2.pdf

Mayer, E. (2002). Multimedia Learning. The Annual Report of Educational Psychology in Japan, 41, 27-29. https://doi.org/10.5926/arepj1962.41.0_27

Paivio, A. (1980). Imagery as a Private Audiovisual Aid. Instructional Science, 9, 295-309. https://doi.org/10.1007/BF00121763

Paivio, A. (1990). Dual Coding Theory. In Mental Representations: A Dual Coding Approach (pp. 583-605). Oxford: Oxford University Press. https://doi.org/10.1093/acprof:oso/9780195066661.003.0004

Piaget, J. (1964). Part 1 Cognitive Development in Children: Piaget Development and Learning. Journal of Research in Science Teaching, 2, 176-186. https://doi.org/10.1002/tea.3660020306

Razali, N. A. M., \& Tasir, Z. (2008). Sistem Pembelajaran Konsep Nombor Berasaskan Strategi Permainan dalam buku Inovasi Bahan Pengajaran dan Pembelajaran Berasaskan Komputer. Skudai: Penerbit UTM.

Richardson, A. (2013). Mental Imagery. Berlin: Springer.

Sang, M. S. (2003). Ilmu Pendidikan Untuk KPLI Sekolah Rendah: Psikologi Pendidikan \& Pedagogi. Subang Jaya: Kumpulan Budiman Sdn Bhd.

Sang, M. S. (2008). Psikologi Pendidikan \& Pedagogi. Subang Jaya: Kumpulan Budiman 
Sdn Bhd.

Shamsudin (2012). Pendidikan Pemulihan. http://desakedah.blogspot.com

Singh, R. K. J. (2012). Pedagogi. Kuala Lumpur: Kumpulan Budiman Sd. Bhd.

Tukimin, R., Yusoff, N. M. R. N., Baharudin, H., \& Hussain, F. (2018). Innovative Arabic Language Teacher: A Dream or a Hope. International Journal of Academic Research in Progressive Education and Development, 7, 158-165.

Vygotsky, L. S. (1975). Multilingualism in Children (Gulutsan, M. and Arki, I., Trans.). Edmonton: The University of Alberta.

Wright, A., \& Hill, D. A. (2008). Writing Stories: Developing Language Skills through Story Making. London: Helbling Languages.

Yahaya, A., Hashim, S., \& Boon, Y. (2008). Psikologi Pendidikan. Skudai: Penerbit UTM.

Yusoff, Z. M., \& Suratem, N. A. (2015). Senario Semasa Dan Strategi Pengembangan Pengajian Ilmu Al-Quran. 